Check for updates

Cite this: Chem. Sci., 2018, 9, 6580

๑ All publication charges for this article have been paid for by the Royal Society of Chemistry

Received 8th June 2018

Accepted 26th June 2018

DOI: $10.1039 / \mathrm{c} 8 \mathrm{sc} 02536 \mathrm{c}$

rsc.li/chemical-science

\section{Synthesis and reactivity of a nickel(II) thioperoxide complex: demonstration of sulfide-mediated $\mathrm{N}_{2} \mathrm{O}$ reduction $\uparrow$}

\begin{abstract}
Nathaniel J. Hartmann, Guang Wu and Trevor W. Hayton (D) *

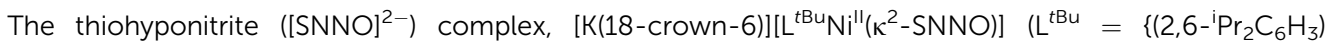

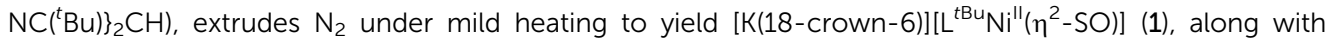
minor products $[K(18-c r o w n-6)]\left[L^{t B u} \mathrm{Ni}^{\prime \prime}\left(\eta^{2}-\mathrm{OSSO}\right)\right]$ (2) and $[K(18-c r o w n-6)]\left[\mathrm{L}^{\mathrm{tBu}} \mathrm{Ni} \mathrm{Ni}^{\prime \prime}\left(\eta^{2}-\mathrm{S}_{2}\right)\right]$ (3). Subsequent reaction of 1 with carbon monoxide (CO) results in the formation of [K(18-crown-6)]

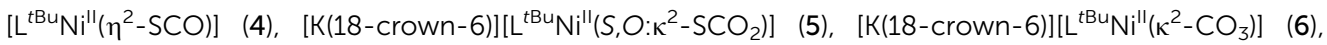
carbonyl sulfide (COS) (7), and $[K(18-c r o w n-6)]\left[L^{t B u} \mathrm{Ni}^{\prime \prime}\left(\mathrm{S}_{2} \mathrm{CO}\right)\right](8)$. To rationalize the formation of these products we propose that 1 first reacts with $\mathrm{CO}$ to form $[\mathrm{K}(18-\mathrm{crown}-6)]\left[\mathrm{L}^{\mathrm{tBu}} \mathrm{Ni} \mathrm{I}^{\mathrm{l}}(\mathrm{S})\right]$ (I) and $\mathrm{CO}_{2}$, via Oatom abstraction. Subsequently, complex I reacts with $\mathrm{CO}$ or $\mathrm{CO}_{2}$ to form 4 and 5 , respectively. Similarly, the formation of complex 6 and $\operatorname{COS}$ can be rationalized by the reaction of 1 with $\mathrm{CO}_{2}$ to form a putative $\mathrm{Ni}(\Perp)$ monothiopercarbonate, $[\mathrm{K}(18-\mathrm{crown}-6)]\left[\mathrm{L}^{\mathrm{tBu}} \mathrm{Ni}^{\prime \prime}\left(\kappa^{2}-\mathrm{SOCO}_{2}\right)\right]$ (11). The $\mathrm{Ni}(\Perp)$ monothiopercarbonate subsequently transfers a S-atom to $\mathrm{CO}$ to form $\mathrm{COS}$ and [K(18-crown-6)] $\left[\mathrm{L}^{\mathrm{tBu}} \mathrm{Ni}{ }^{11}\left(\mathrm{~K}^{2}-\mathrm{CO}_{3}\right)\right]$ (6). Finally, the formation of 8 can be rationalized by the reaction of COS with $\mathrm{I}$. Critically, the observation of complexes 4 and 5 in the reaction mixture reveals the stepwise conversion of [K(18-crown-6)] [L $\left.{ }^{t B u} \mathrm{Ni}^{\prime \prime}\left(\kappa^{2}-\mathrm{SNNO}\right)\right]$ to 1 and then $\mathrm{l}$, which represents the formal reduction of $\mathrm{N}_{2} \mathrm{O}$ by $\mathrm{CO}$.
\end{abstract}

\section{Introduction}

Nitrous oxide $\left(\mathrm{N}_{2} \mathrm{O}\right)$ features a long atmospheric lifetime and large global warming potential ( $\mathrm{ca} .300$ times larger than $\mathrm{CO}_{2}$ ), making it an important greenhouse gas. ${ }^{\mathbf{1 - 4}}$ Anthropogenic sources of $\mathrm{N}_{2} \mathrm{O}$ include agriculture, fossil fuel combustion, adipic acid synthesis, and nitric acid production. ${ }^{1,5}$ The latter two sources use on-site $\mathrm{N}_{2} \mathrm{O}$ mitigation to remove $\mathrm{N}_{2} \mathrm{O}$ from the effluent stream, either by decomposition to the elements ${ }^{6}$ or reduction to $\mathrm{N}_{2}$ and $\mathrm{H}_{2} \mathrm{O}$, but neither of these methods is completely effective and some $\mathrm{N}_{2} \mathrm{O}$ is still released into the atmosphere. $^{7}$

Given the above considerations, the development of new catalysts for $\mathrm{N}_{2} \mathrm{O}$ reduction could help reduce its impact on global temperatures. ${ }^{\mathbf{1 , 8}}$ Not surprisingly, a large number of heterogeneous systems have been developed to catalyze this reaction. ${ }^{9}$ Of most relevance to the current study are the catalyst systems used for automotive applications, which consist of nanoparticulate $\mathrm{Pt}$ and $\mathrm{Rh}$ on a ceramic support. This process uses partially oxidized fuel (i.e., $\mathrm{CO}$ ) to reduce $\mathrm{N}_{2} \mathrm{O}$, forming $\mathrm{N}_{2}$

Department of Chemistry and Biochemistry, University of California, Santa Barbara, California, 93106 USA. E-mail: hayton@chem.ucsb.edu

$\dagger$ Electronic supplementary information (ESI) available: Experimental and crystallographic details and spectral data. CCDC 1847162-1847167. For ESI and crystallographic data in CIF or other electronic format see DOI: $10.1039 / \mathrm{c} 8 \mathrm{sc} 02536 \mathrm{c}$ and $\mathrm{CO}_{2} \cdot{ }^{9}$ Sita and co-workers developed a homogeneous version of this transformation, mediated by the Mo(II) complex, $\mathrm{Cp}{ }^{*} \mathrm{Mo}(\mathrm{NCN})(\mathrm{CO})_{2}\left(\mathrm{NCN}={ }^{\mathrm{i}} \operatorname{PrNC}(\mathrm{Me}) \mathrm{N}^{\mathrm{i}} \mathrm{Pr}\right) .{ }^{10}$ In this process, $\mathrm{N}_{2} \mathrm{O}$ oxidizes $\mathrm{Cp}^{*} \mathrm{Mo}(\mathrm{NCN})(\mathrm{CO})_{2}$ to form a $\mathrm{Mo}(\mathrm{Iv})$ oxo, $\mathrm{Cp} * \mathrm{Mo}(\mathrm{NCN})(\mathrm{O})$, which then reacts with $\mathrm{CO}$ to form $\mathrm{CO}_{2}$ and regenerate $\mathrm{Cp} * \mathrm{Mo}(\mathrm{NCN})(\mathrm{CO})_{2}$. However, an $\mathrm{N}-\mathrm{N}$ bond cleavage reaction, which results in irreversible formation of $\mathrm{Cp} * \mathrm{Mo}(\mathrm{NCN})(\mathrm{NCO})(\mathrm{NO})$, was found to be competitive with oxo formation. Similarly, Limberg and co-workers reported the stoichiometric oxidation of a $\mathrm{Ni}(0)$ CO complex, $[\mathrm{K}]_{2^{-}}$ $\left[\mathrm{L}^{t \mathrm{Bu}} \mathrm{Ni}^{\mathrm{O}}(\mathrm{CO})\right]_{2}$, with $\mathrm{N}_{2} \mathrm{O}$ to form a carbonate complex, $[\mathrm{K}]_{6^{-}}$ $\left[\mathrm{L}^{t \mathrm{Bu}} \mathrm{Ni}^{\mathrm{II}}\left(\mathrm{CO}_{3}\right)\right]_{6}$, and $\mathrm{N}_{2} \cdot{ }^{11}$ Subsequent release of carbonate from the metal center was not discussed. The homogeneous hydrogenation of $\mathrm{N}_{2} \mathrm{O}$ has also been explored. ${ }^{12,13}$ For example, in 2015 Piers and co-workers reported an $\operatorname{Ir}($ III) pincer carbene complex that could hydrogenate $\mathrm{N}_{2} \mathrm{O} ;{ }^{14}$ however, this system was not reported to be catalytic. More recently, Milstein and coworkers reported that the $\mathrm{Ru}$ pincer complex, [(PNP)RuH$(\mathrm{CO})(\mathrm{OH})]\left(\mathrm{PNP}=2,6-\left[\mathrm{CH}_{2} \mathrm{P}^{\mathrm{i}} \mathrm{Pr}_{2}\right]_{2}\left(\mathrm{C}_{5} \mathrm{H}_{3} \mathrm{~N}\right)\right)$, was an effective catalyst for the hydrogenation of $\mathrm{N}_{2} \mathrm{O}$, achieving a turnover number of $c a .400 .^{15}$

Recently, we reported the activation of $\mathrm{N}_{2} \mathrm{O}$ by the "masked" terminal nickel sulfide complex, [K(18-crown-6)][$\left[\mathrm{L}^{t \mathrm{Bu}} \mathrm{Ni}^{\mathrm{II}}(\mathrm{S})\right](\mathrm{I})$ $\left(\mathrm{L}^{t \mathrm{Bu}}=\left\{\left(2,6{ }^{\mathrm{i}}{ }^{\mathrm{i}} \mathrm{Pr}_{2} \mathrm{C}_{6} \mathrm{H}_{3}\right) \mathrm{NC}\left({ }^{t} \mathrm{Bu}\right)\right\}_{2} \mathrm{CH}\right)$, which yielded an unprecedented thiohyponitrite complex, $\left[\mathrm{K}\left(18\right.\right.$-crown-6)][ $\mathrm{L}^{t \mathrm{Bu}} \mathrm{Ni}^{\mathrm{II}}\left(\kappa^{2}\right.$ SNNO)] (II) (eqn (1)). ${ }^{16}$ Given the challenge of activating $\mathrm{N}_{2} \mathrm{O},{ }^{17}$ and the novelty of the $[\mathrm{SNNO}]^{2-}$ ligand in II, we endeavored to 
explore its reactivity in greater detail. Herein, we describe the first reactivity study of the $[\mathrm{SNNO}]^{2-}$ ligand in an effort to uncover new routes to $\mathrm{N}_{2} \mathrm{O}$ reduction.

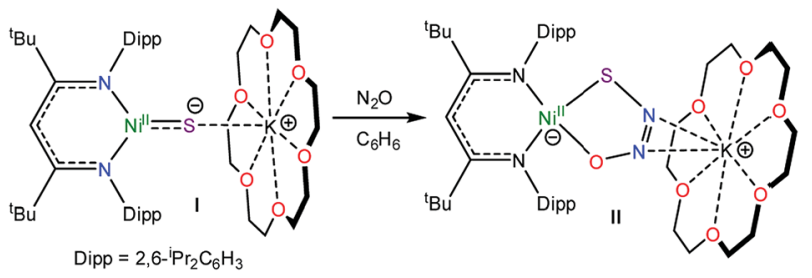

\section{Results and discussion}

\section{Synthesis of an $\left[\eta^{2}-\mathrm{SO}\right]^{2-}$ complex}

Gentle heating of a toluene- $\mathrm{d}_{8}$ solution of $[\mathrm{K}(18-$ crown- 6$)]\left[\mathrm{L}^{t \mathrm{Bu}-}\right.$ $\left.\mathrm{Ni}^{\mathrm{II}}\left(\kappa^{2}-\mathrm{SNNO}\right)\right]$ (II) at $45{ }^{\circ} \mathrm{C}$ results in the complete disappearance of II over the course of $6 \mathrm{~d}$. A ${ }^{1} \mathrm{H}$ NMR spectrum of this reaction mixture reveals the presence of a new $\gamma-\mathrm{CH}$ resonance at $5.43 \mathrm{ppm}$ (Fig. S2 and $3 \dagger$ ), which we have assigned to the

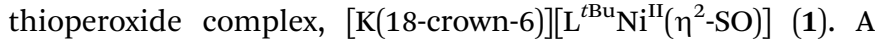
preliminary kinetic analysis suggests that the formation of $\mathbf{1}$ is first-order with respect to complex II, indicating that this transformation is unimolecular (Fig. S25 $\dagger$ ). Also present in these spectra are two minor $\gamma-\mathrm{CH}$ resonances. The first, observed at $5.53 \mathrm{ppm}$, has been tentatively assigned to the

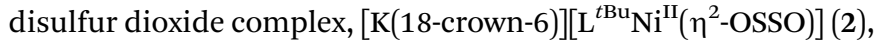
and the second resonance at $5.47 \mathrm{ppm}$, has been assigned to the disulfide complex, $\left[\mathrm{K}\left(18\right.\right.$-crown-6)][ $\left.\mathrm{L}^{t \mathrm{Bu}} \mathrm{Ni}^{\mathrm{II}}\left(\eta^{2}-\mathrm{S}_{2}\right)\right]$ (3). Work-up

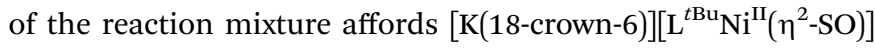
(1) as an orange crystalline solid in $82 \%$ yield (eqn (2)). The solid state molecular structure of $\mathbf{1}$ is shown in Fig. 1. Complex $\mathbf{1}$ features a rare example of an $\eta^{2}$-thioperoxide $\left(\left[\eta^{2}-\mathrm{SO}\right]^{2-}\right)$ ligand, which is formed via $\mathrm{N}_{2}$ extrusion from the thiohyponitrite fragment. The $\left[\eta^{2}-\mathrm{SO}\right]^{2-}$ ligand in $\mathbf{1}$ is disordered over two positions in a $97: 3$ ratio, which are related by a $\mathrm{C}_{2}$ rotation about the $\mathrm{Ni}-\mathrm{K}$ axis. It possesses an S-O bond length of 1.656(3) $\AA$, consistent with an S-O single bond..$^{18}$ For comparison, the S-O distance in free $\mathrm{S}=\mathrm{O}$ is substantially shorter $(1.48108(8) \AA)$, due to its higher bond order. ${ }^{19}$ The Ni-S (2.127(1) $\left.\AA\right)$ and Ni-O (1.954(3) $\AA$ ) distances in 1 are both consistent with single bonds and are comparable with those found in the starting material (II), while the $\mathrm{Ni}-\mathrm{N}$ bond lengths (1.881(4) and 1.900(4) $\AA$ ) are similar to those observed in other square planar $\mathrm{L}^{\mathrm{R}} \mathrm{Ni}^{\mathrm{II}}$ complexes. ${ }^{16,20}$

The ${ }^{1} \mathrm{H}$ and ${ }^{13} \mathrm{C}\left\{{ }^{1} \mathrm{H}\right\}$ NMR spectra of $\mathbf{1}$ are consistent with its formulation as a $C_{\mathrm{s}}$ symmetric, diamagnetic, square planar $\mathrm{Ni}^{\mathrm{II}}$ complex. The ${ }^{1} \mathrm{H}$ NMR spectrum of $\mathbf{1}$ in $\mathrm{C}_{6} \mathrm{D}_{6}$ features two tertbutyl resonances at 1.32 and $1.37 \mathrm{ppm}$ and a single $\gamma$-CH resonance at $5.54 \mathrm{ppm}$. The IR spectrum (KBr pellet) of 1 reveals a strong $v_{\text {So }}$ mode at $902 \mathrm{~cm}^{-1}$, which is consistent with values reported for other $\left[\eta^{2}-\mathrm{SO}\right]^{2-}$ ligands $\left(883,873 \mathrm{~cm}^{-1}\right) .^{21,22}$ Only a handful of structurally-characterized thioperoxide complexes are known, ${ }^{23-26}$ including [(triphos) $\mathrm{Rh}\left(\mu-\eta^{2}, \eta^{1}-\mathrm{SO}\right)_{2} \mathrm{Rh}($ triphos $\left.)\right]$ $\left[\mathrm{BPh}_{4}\right]_{2} \quad$ (triphos $\left.=\mathrm{CH}_{3} \mathrm{C}\left(\mathrm{CH}_{2} \mathrm{PPh}_{2}\right)_{3}\right), \quad\left[\left\{\mathrm{RhCl}\left(\mu-\eta^{2}, \eta^{1}-\right.\right.\right.$ $\left.\left.\mathrm{SO})\left(\mathrm{PPh}_{3}\right)_{2}\right\}_{2}\right]$, and $\mathrm{Fe}_{3}\left(\mu_{3}-\mathrm{SO}\right)(\mathrm{S})(\mathrm{CO})_{9} \cdot{ }^{21,27,28}$ The iron example is notable because it can be prepared by O-atom transfer to

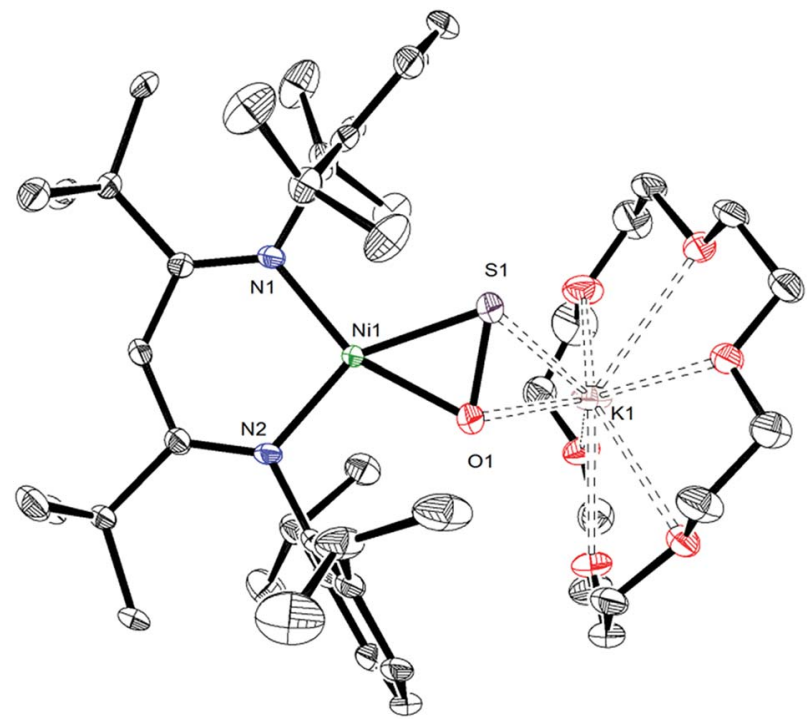

Fig. 1 ORTEP drawing of $\left[K\left(18\right.\right.$-crown-6)][ $\left.\mathrm{L}^{\mathrm{tBu}} \mathrm{Ni}^{i \prime}\left(\eta^{2}-\mathrm{SO}\right)\right] \cdot \mathrm{C}_{7} \mathrm{H}_{8}$ $\left(1 \cdot \mathrm{C}_{7} \mathrm{H}_{8}\right)$ shown with $50 \%$ thermal ellipsoids. Hydrogen atoms, a $\mathrm{C}_{7} \mathrm{H}_{8}$ solvate molecule, and one orientation of the disordered $\left[\eta^{2}-\mathrm{SO}\right]^{2-}$ ligand have been omitted for clarity. Selected metrical parameters: S1-

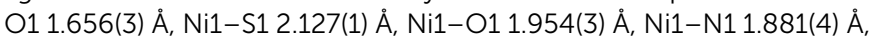
Ni1-N2 1.900(4) Å, S1-K1 3.162(2) A, O1-K1 2.881(3) Å, N1-Ni1-N2

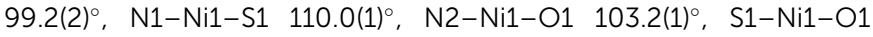
$47.65(9)^{\circ}$

$\mathrm{Fe}_{3}(\mathrm{~S})_{2}(\mathrm{CO})_{9},{ }^{29}$ a manner of preparation that is similar to that of 1. Interestingly, Mankad and co-workers suggest that a transient SO complex is formed upon reaction of $\left[\left(\mathrm{IPr}^{*}\right) \mathrm{Cu}\right]_{2}(\mu-\mathrm{S})$ with $\mathrm{N}_{2} \mathrm{O},{ }^{30}$ a transformation that parallels our conversion of $\mathbf{I}$ to $\mathbf{I I}$ and then 1.

As mentioned above, we also observe formation of [K(18-

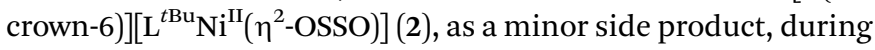

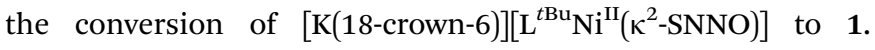
Despite its presence in trace amounts, we have been able to obtain a few single crystals of 2 as orange plates from the reaction mixture. The solid state molecular structure of 2 is shown in Fig. 2. It features the first example of a co-planar $[\mathrm{OSSO}]^{2-}$ ligand (OSSO dihedral angle $=2^{\circ}$ ). The $\left[\eta^{2}-\mathrm{OSSO}\right]^{2-}$ ligand in 2 is bound to the Ni center in an $\eta^{2}$ fashion, via both sulfur atoms, while the $\mathrm{O}$ atoms are bound to the [K(18-crown6)] $]^{+}$cation in a $\kappa^{2}$ fashion. Its S-S distance is 2.093(3) $\AA$, while the S-O distances are 1.485(5) and 1.496(7) $\AA$. For comparison, the S-S (2.0245(6) ̊̊) and S-O (1.458(2) $\AA$ ) distances in free $\mathrm{S}_{2} \mathrm{O}_{2}$ are shorter than those observed for $\mathbf{2 ,}^{31-33}$ consistent with the reduced $\mathrm{S}-\mathrm{S}$ and $\mathrm{S}-\mathrm{O}$ bond orders anticipated for the $[\mathrm{OSSO}]^{2-}$ fragment in the former. ${ }^{31,34,35}$ Notably, complex 2 is only the third OSSO complex to be reported and only second to be structurally characterized..$^{29,36-38}$

To account for the presence of 2 in the reaction mixture, we hypothesize that complex 1 undergoes a formal disproportionation, forming 2 and an equivalent of unobserved "[K(18-crown6) $]\left[{ }^{t \mathrm{Bu}} \mathrm{Ni}^{0}\right]$ ". However, because of the low yield (typically less than $3 \%$ relative to complex 1 , as assessed by ${ }^{1} \mathrm{H}$ NMR spectroscopy), this transformation must be very inefficient. The low yield has also impeded our ability to fully characterize this complex. 


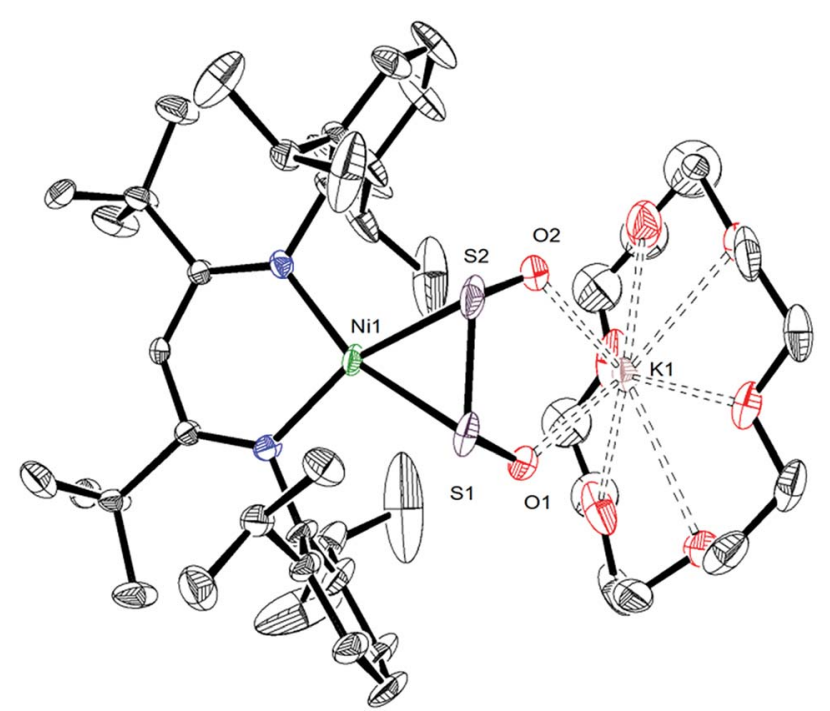

Fig. 2 ORTEP drawing of [K(18-crown-6)][L $\left.{ }^{t B u} \mathrm{Ni}^{\prime \prime}\left(\eta^{2}-\mathrm{OSSO}\right)\right] \cdot 2 \mathrm{C}_{6} \mathrm{H}_{14}$ $\left(2 \cdot 2 \mathrm{C}_{6} \mathrm{H}_{14}\right)$ shown with $50 \%$ thermal ellipsoids. Hydrogen atoms and $\mathrm{C}_{6} \mathrm{H}_{14}$ solvate molecules have been omitted for clarity. Selected metrical parameters: S1-S2 2.093(3) A, S1-O1 1.485(5) A, S2-O2 1.496(7) Å, Ni1-S1 2.181(2) A, Ni1-S2 2.173(2) Å, Ni1-N1 1.920(4) Å, $\mathrm{Ni1}-\mathrm{N} 2$ 1.925(4) $\AA$, O1-K1 2.747(4) $\AA$, O2-K1 2.777(6) Å, N1-Ni1-N2 $97.3(2)^{\circ}, \quad \mathrm{N} 1-\mathrm{Ni} 1-\mathrm{S} 1 \quad 102.1(1)^{\circ}, \mathrm{N} 2-\mathrm{Ni} 1-\mathrm{S} 2$ 102.9(1) ${ }^{\circ}, \mathrm{O} 1-\mathrm{S} 1-\mathrm{S} 2$ $107.4(2)^{\circ}, \mathrm{O} 2-\mathrm{S} 2-\mathrm{S} 1107.4(2)^{\circ}$.

\section{Synthesis of an $\left[\eta^{2}-S_{2}\right]^{2-}$ complex}

To further support the formation of the disulfide $\left(\left[\eta^{2}-S_{2}\right]^{2-}\right)$ complex, $\quad\left[\mathrm{K}\left(18\right.\right.$-crown-6)][$\left[\mathrm{L}^{t \mathrm{Bu}} \mathrm{Ni}^{\mathrm{II}}\left(\eta^{2}-\mathrm{S}_{2}\right)\right]$ (3), during the synthesis of $\mathbf{1}$, we endeavored to independently synthesize 3 . We, and others, have previously shown that terminal metal sulfides can react with $\mathrm{S}_{8}$ to form metal disulfides. ${ }^{39-41}$ Thus, we explored the reaction of $\left[\mathrm{K}\left(18-\right.\right.$ crown $\left.\left.^{-6}\right)\right]\left[\mathrm{L}^{t \mathrm{Bu}} \mathrm{Ni}^{\mathrm{II}}(\mathrm{S})\right]$ (I) with elemental sulfur. Addition of 0.125 equiv. of $\mathrm{S}_{8}$ to a toluene solution of $\left[\mathrm{K}\left(18-\right.\right.$ crown-6)][ $\left.\mathrm{L}^{\mathrm{tBu}} \mathrm{Ni}^{\mathrm{II}}(\mathrm{S})\right]$ results in a rapid color change from brown to orange. Work-up of the reaction mixture

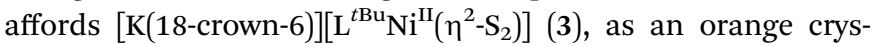
talline solid in $81 \%$ yield (eqn (3)). The solid state molecular structure of 3 is shown in Fig. 3. The disulfide $\left(\mathrm{S}_{2}{ }^{2-}\right)$ ligand in 3 has a S-S distance of 2.050(2) $\AA$, consistent with a single bond. ${ }^{18}$ This distance is comparable to those reported for other $\mathrm{Ni}^{\mathrm{II}}\left(\eta^{2}\right.$ $\mathrm{S}_{2}$ ) complexes. ${ }^{42-49}$ The Ni-S distances (2.202(2) and 2.199(2) $\AA$ ) in 3 are consistent with single bonds, and are much longer than the Ni-S bond length in the starting material (I, 2.064(2) ̊). Finally, the Ni-N bonds in 3 are similar to those found in other square planar $\mathrm{Ni}^{\mathrm{II}} \beta$-diketiminate complexes. ${ }^{16,49,50}$

The ${ }^{1} \mathrm{H}$ NMR spectrum of 3 in toluene- $\mathrm{d}_{8}$ (Fig. S7 $\dagger$ ) is consistent with a $C_{2 \mathrm{v}}$ symmetric, diamagnetic, square planar

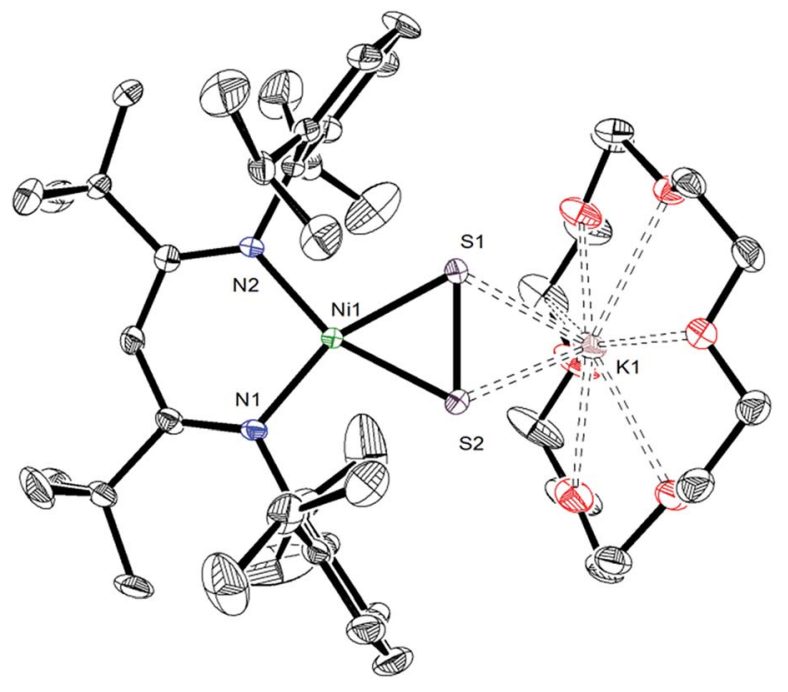

Fig. 3 ORTEP drawing of $\left[K\left(18-\right.\right.$ crown-6)][L $\left.{ }^{\text {Bu }} \mathrm{Ni}^{\prime \prime}\left(\eta^{2}-\mathrm{S}_{2}\right)\right] \cdot 2 \mathrm{C}_{7} \mathrm{H}_{8}$ $\left(3 \cdot 2 \mathrm{C}_{7} \mathrm{H}_{8}\right)$ shown with $50 \%$ thermal ellipsoids. Hydrogen atoms and $\mathrm{C}_{7} \mathrm{H}_{8}$ solvate molecules have been omitted for clarity. Selected metrical parameters: S1-S2 2.050(2) A, Ni1-S1 2.202(2) A, Ni1-S2 2.199(2) A, Ni1-N1 1.900(4) Å, Ni1-N2 1.906(4) Å, S1-K1 3.248(2) A,

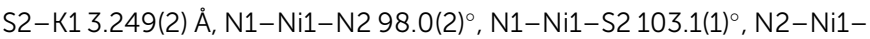
S1 $103.4(1)^{\circ}$.

$\mathrm{Ni}^{\mathrm{II}}$ complex and features one tert-butyl resonance at $1.30 \mathrm{ppm}$ and a single $\gamma-\mathrm{CH}$ resonance at $5.46 \mathrm{ppm}$. Importantly, this latter resonance is also present in the in situ ${ }^{1} \mathrm{H}$ NMR spectrum of the thermolysis of II (Fig. S3†), confirming the formation of 3 during that reaction, via an as-yet-unknown mechanism.

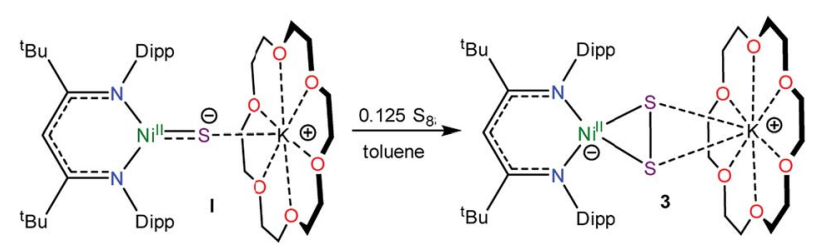

\section{Reactivity of the $\left[\eta^{2}-S O\right]^{2-}$ ligand}

While the reactivity of the SO ligand has not been well established, it is known to react with phosphines. For example, Schmid and co-workers reported that [(diphos $\left.)_{2} \operatorname{Ir}\left(\eta^{2}-\mathrm{OSSO}\right)\right][\mathrm{Cl}]$ reacted with $\mathrm{PPh}_{3}$ to form $\mathrm{Ph}_{3} \mathrm{PO}, \mathrm{Ph}_{3} \mathrm{PS}$, and [(diphos) $\left.)_{2} \mathrm{IrCl}\right] .^{36}$ Similarly, Rauchfuss and co-workers demonstrated that $\mathrm{Cp}_{2}$ $\mathrm{Nb}\left(\mathrm{S}_{2} \mathrm{O}\right) \mathrm{Cl}$ reacted with $\mathrm{Ph}_{3} \mathrm{P}$ to form $\mathrm{Cp}_{2} \mathrm{Nb}(\mathrm{O}) \mathrm{Cl}$ and two equiv. of $\mathrm{Ph}_{3} \mathrm{PS}^{29}$ Both transformations were presumed to proceed through an unobserved SO intermediate. More recently, Mizobe et al. reported that $\mathrm{PPh}_{3}$ could abstract an O-atom from the
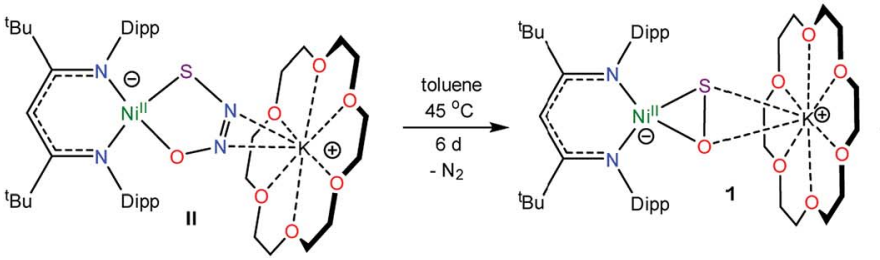

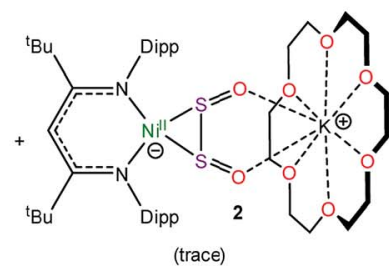

(trace)

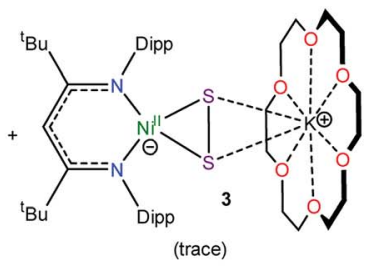


thioperoxide ligand in $\left[\left(\mathrm{Cp}^{\prime} \mathrm{RuCl}\right)_{2}\left(\mathrm{SbCl}_{2}\right)(\mu-\mathrm{Cl})\left(\mu_{3}: \kappa^{2}-\mathrm{SO}\right)\right]\left(\mathrm{Cp}^{\prime}\right.$ $\left.=\mathrm{C}_{5} \mathrm{Me}_{4} \mathrm{Et}\right){ }_{.}{ }^{25} \mathrm{In}$ contrast, the reactivity of the SO ligand with $\mathrm{CO}$ has not been studied. Accordingly, we explored the reactivity of $\left[\mathrm{K}\left(18-\right.\right.$ crown-6)][$\left[\mathrm{L}^{t \mathrm{Bu}} \mathrm{Ni}^{\mathrm{iI}}\left(\eta^{2}-\mathrm{SO}\right)\right]$ (1) with this substrate. Thus, exposure of a $\mathrm{C}_{6} \mathrm{D}_{6}$ solution of complex $\mathbf{1}$ to an atmosphere of ${ }^{13} \mathrm{CO}$ results in complete consumption of 1 after 6 h. A ${ }^{13} \mathrm{C}\left\{{ }^{1} \mathrm{H}\right\}$ NMR spectrum (Fig. S11 $\dagger$ ) of the reaction mixture reveals the formation of several ${ }^{13} \mathrm{C}$-enriched products, indicating the incorporation of ${ }^{13} \mathrm{CO}$. Specifically, this spectrum features resonances at $214.7,177.3,165.3$, and $152.9 \mathrm{ppm}$, which are assignable to $[\mathrm{K}(18$-crown- 6$)]\left[\mathrm{L}^{t \mathrm{Bu}} \mathrm{Ni}^{\mathrm{II}}\left(\eta^{2}-\mathrm{SCO}\right)\right](4),{ }^{51}[\mathrm{~K}(18-$

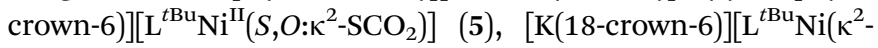
$\left.\left.\mathrm{CO}_{3}\right)\right](6)$, and $\mathrm{SCO}(7),{ }^{52}$ respectively (Scheme 1). This spectrum also features a minor ${ }^{13} \mathrm{C}$-enriched resonance at $206.9 \mathrm{ppm}$, which we have tentatively assigned to [K(18-crown-6)] $\left[\mathrm{L}^{t \mathrm{Bu}} \mathrm{Ni}^{\mathrm{II}}\left(\mathrm{S}_{2} \mathrm{CO}\right)\right](8)$, on the basis of the similarity of its dithiocarbonate $\left(\left[\mathrm{S}_{2} \mathrm{CO}\right]^{2-}\right)$ chemical shift with those reported for other dithiocarbonate complexes. ${ }^{52-54}$

$\mathrm{A}^{1} \mathrm{H}$ NMR spectrum of the reaction mixture further supports these assignments. Specifically, an examination of the $\gamma-\mathrm{CH}$ region of this spectrum reveals overlapping resonances at $5.48 \mathrm{ppm}$ (Fig. S10 $\dagger$ ), which are assignable to [K(18-crown-6)] $\left[\mathrm{L}^{t \mathrm{Bu}} \mathrm{Ni}^{\mathrm{II}}\left(\eta^{2}-\mathrm{SCO}\right)\right] \quad(4)^{51}$ and $[\mathrm{K}(18-$ crown- 6$)]\left[\mathrm{L}^{t \mathrm{Bu}} \mathrm{Ni}^{\mathrm{II}}\left(S, O: \kappa^{2}-\right.\right.$ $\left.\left.\mathrm{SCO}_{2}\right)\right](5)$, and a resonance at $5.42 \mathrm{ppm}$, assignable to $[\mathrm{K}(18-$ crown-6)][[ $\left.\mathrm{L}^{t \mathrm{Bu}} \mathrm{Ni}\left(\kappa^{2}-\mathrm{CO}_{3}\right)\right]$ (6). This spectrum also contains a minor resonance at $5.57 \mathrm{ppm}$ that has been tentatively assigned to $[\mathrm{K}(18$-crown-6) $)]\left[\mathrm{L}^{t \mathrm{Bu}} \mathrm{Ni}^{\mathrm{II}}\left(\mathrm{S}_{2} \mathrm{CO}\right)\right](8)$. Interestingly, at short reaction times, we observe the presence of a paramagnetic intermediate in the reaction mixture (Fig. S9†). We have identified this intermediate as the $\mathrm{Ni}^{\mathrm{II}}$ sulfide, $\left[\mathrm{K}(18\right.$-crown-6) $]\left[\mathrm{L}^{t \mathrm{Bu}-}\right.$ $\left.\mathrm{Ni}^{\mathrm{II}}(\mathrm{S})\right]$ (I), on the basis of the similarity of its ${ }^{1} \mathrm{H}$ NMR resonances with those of the previously characterized material. ${ }^{16}$ For example, this intermediate features diagnostic resonances at $-130.25,-0.63$, and $5.87 \mathrm{ppm}$, which are assignable to the $\gamma$-proton of the $\mathrm{L}^{t \mathrm{Bu}}$ ligand, its ${ }^{t} \mathrm{Bu}$ substituents, and one environment of its diastereotopic ${ }^{\mathrm{i}} \mathrm{Pr}$ methyl groups, respectively. For comparison, these resonances appear at -115.21 , -0.88 , and $6.56 \mathrm{ppm}$, respectively, for authentic $\mathbf{I}^{16}$ This intermediate is quickly formed upon addition of ${ }^{13} \mathrm{CO}$, but its signals immediately begin to decay, and they are completely absent after 6 h (Fig. S9†).

We also characterized the products of the reaction of $\mathbf{1}$ and $\mathrm{CO}$ by IR spectroscopy. An IR spectrum of the reaction residue, dissolved in hexanes, reveals the presence of $v_{\mathrm{CO}}$ modes at 2021, 1666 , and $1620 \mathrm{~cm}^{-1}$ (Fig. S24†), which are assignable to the $v_{\mathrm{CO}}$ modes of $\left[\mathrm{L}^{\mathrm{tBu}} \mathrm{Ni}(\mathrm{CO})\right](9),{ }^{55}\left[\mathrm{~K}(18-\right.$ crown-6) $]\left[\mathrm{L}^{\mathrm{tBu}} \mathrm{Ni}^{\mathrm{II}}\left(\eta^{2}-\mathrm{SCO}\right)\right](4),{ }^{51}$ and $\left[\mathrm{K}\left(18-\right.\right.$ crown-6)][ $\left.{ }^{t \mathrm{Bu}} \mathrm{Ni}^{\mathrm{II}}\left(\kappa^{2}-\mathrm{CO}_{3}\right)\right](6)$, respectively. Curiously, though, we do not observe any signals in the ${ }^{1} \mathrm{H}$ NMR spectrum of the reaction mixture that could be assigned to paramagnetic $\mathbf{9}$, suggesting that it is only a minor product of the reaction.

The ${ }^{13} \mathrm{C}$ NMR spectrum of the in situ reaction mixture also features a minor ${ }^{13} \mathrm{C}$-enriched resonance at 178.5 , as well as a major resonance at 191.4 ppm (Fig. S11†). While these two resonances remain unassigned, we know that neither of the peaks is assignable to $\left[\mathrm{K}\left(18\right.\right.$-crown-6)][$\left[\mathrm{L}^{t \mathrm{Bu}} \mathrm{Ni}^{\mathrm{II}}\left(\eta^{2}-\mathrm{CO}_{2}\right)\right](\mathbf{1 0})$, as we have performed the independent synthesis of this complex for spectroscopic comparison (see below). We also do not observe a resonance that could be assignable to free $\mathrm{CO}_{2}$.

Finally, we observe no reaction between [K(18-crown-6)] $\left[\mathrm{L}^{t \mathrm{Bu}} \mathrm{Ni}^{\mathrm{II}}\left(\eta^{2}-\mathrm{SO}\right)\right](\mathbf{1})$ and $\mathrm{PPh}_{3}$ in $\mathrm{C}_{6} \mathrm{D}_{6}$, according to ${ }^{1} \mathrm{H}$ and ${ }^{31} \mathrm{P}$ NMR spectroscopies. The lack of reactivity of the $[\mathrm{SO}]^{2-}$ ligand in 1 with $\mathrm{PPh}_{3}$ is somewhat surprising on the basis of thermodynamic considerations, ${ }^{56}$ and could reflect steric shielding of the $[\mathrm{SO}]^{2-}$ ligand by the bulky Dipp substituents.

\section{Synthesis of an $\left[\mathrm{S}, \mathrm{O}: \mathrm{K}^{2}-\mathrm{SCO}_{2}\right]^{2-}$ complex}

To further support the formation of $\left[\mathrm{K}\left(18\right.\right.$-crown-6)][ $\mathrm{L}^{\mathrm{tBu}} \mathrm{Ni}^{\mathrm{II}}-$ $\left.\left(S, O: \kappa^{2}-\mathrm{SCO}_{2}\right)\right]$ (5) upon reaction of $\mathbf{1}$ with $\mathrm{CO}$, we pursued its synthesis via an independent route. Thus, exposure of a $\mathrm{C}_{6} \mathrm{D}_{6}$ solution of $[\mathrm{K}(18-$ crown-6) $)]\left[\mathrm{L}^{t \mathrm{tBu}} \mathrm{Ni}^{\mathrm{II}}(\mathrm{S})\right]$ (I) to excess carbon dioxide $\left(\mathrm{CO}_{2}\right)$ results in a rapid color change from deep brown to gold. The ${ }^{1} \mathrm{H}$ NMR spectrum of the reaction mixture taken 15 min after addition of $\mathrm{CO}_{2}$ reveals full consumption of the starting material and formation of a new diamagnetic product whose spectroscopic signatures are consistent with a square planar $\mathrm{Ni}^{\mathrm{II}}$ complex. ${ }^{51}$ Work-up of the reaction mixture provides 5 as a pale brown crystalline solid in $57 \%$ yield (eqn (4)). The solid state molecular structure of 5 is shown in Fig. 4. The thiocarbonate $\left(\left[S, O: \kappa^{2}-\mathrm{SCO}_{2}\right]^{2-}\right)$ ligand in 5 features a $\mu: \kappa^{2}, \kappa^{2}$ binding mode and is disordered over two positions, which are related by a $C_{2}$ rotation about the Ni-K vector, in a $87: 13$ ratio. The S-C (1.756(4) ̊) and O-C (1.279(5) and 1.238(4) ̊) bond lengths in $\mathbf{5}$ are consistent with those observed for previously reported $\left[\mathrm{SCO}_{2}\right]^{2-}$ complexes, ${ }^{57,58}$ while the $\mathrm{Ni}-\mathrm{S}$ and $\mathrm{Ni}-\mathrm{O}$ distances are 2.234(1) $\AA$ and 1.922(3) $\AA$, respectively. Moreover, the $\mathrm{K}-\mathrm{S}$ and $\mathrm{K}-\mathrm{O}$ distances are 3.531(1) $\AA$ and 2.715(3) $\AA$, respectively, which are comparable to other $\mathrm{K}-\mathrm{S}$ and $\mathrm{K}-\mathrm{O}$ dative interactions. ${ }^{59,60}$ Finally, the Ni-N distances in $\mathbf{5}$ are comparable to those found in the starting material. ${ }^{16}$ To the best of our

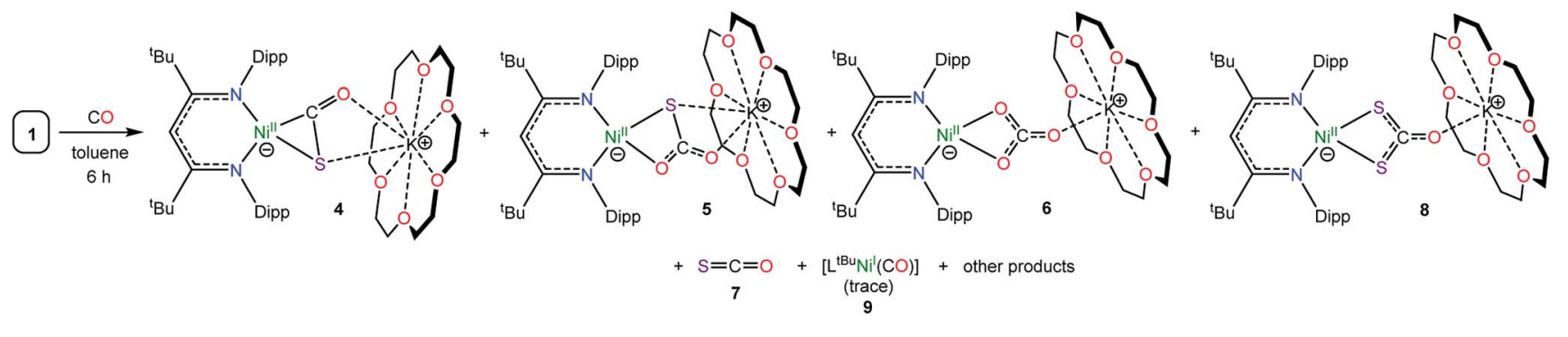

Scheme 1 
knowledge, complex $\mathbf{5}$ is the first structurally characterized transition metal complex containing the $\left[\mathrm{SCO}_{2}\right]^{2-}$ ligand. Other structurally characterized thiocarbonate complexes include $\left.\left[\left\{\left({ }^{\mathrm{Ad}} \mathrm{ArO}\right)_{3} \mathrm{~N}\right) \mathrm{U}\right\}_{2}\left(\mu-\eta^{1},(\mathrm{O}): \kappa^{2}\left(\mathrm{O}^{\prime}, \mathrm{S}\right) \mathrm{SCO}_{2}\right)\right]$, prepared by reaction of $\left.\left[\left\{\left({ }^{\mathrm{Ad}} \mathrm{ArO}\right)_{3} \mathrm{~N}\right) \mathrm{U}\right\}_{2}(\mu-\mathrm{S})\right]$ with $\mathrm{CO}_{2}$, and $\left[\mathrm{Cp}^{*}{ }_{2} \mathrm{Sm}\left(\mu-\eta^{1}: \kappa^{2}-\mathrm{SCO}_{2}\right)\right.$ $\left.\mathrm{SmCp}_{2}{ }_{2}\right]$, prepared via reaction of $\left[\left(\mathrm{Cp}_{2}{ }_{2} \mathrm{Sm}\right)_{2}(\mu-\mathrm{O})\right]$ with COS. ${ }^{57,58}$

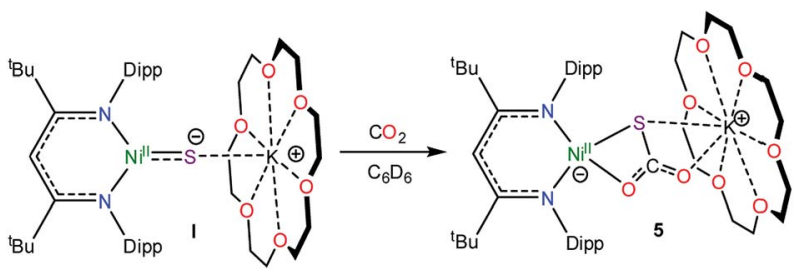

The ${ }^{13} \mathrm{C}\left\{{ }^{1} \mathrm{H}\right\}$ NMR spectrum of 5 in benzene- $\mathrm{d}_{6}$ features a resonance at $177.3 \mathrm{ppm}$, which we have assigned to the $\left[S, O: \kappa^{2}-\right.$ $\left.\mathrm{SCO}_{2}\right]^{2-}$ moiety (Fig. S13 $\dagger$ ). This chemical shift is identical to the resonance assigned to this complex in the in situ ${ }^{13} \mathrm{C}$ NMR spectrum of the reaction of 1 with CO (Fig. S11 $\dagger$ ). Moreover, the ${ }^{1} \mathrm{H}$ NMR spectrum of 5 in $\mathrm{C}_{6} \mathrm{D}_{6}$ features a $\gamma-\mathrm{CH}$ resonance at $5.48 \mathrm{ppm}$. This resonance is also present in the in situ ${ }^{1} \mathrm{H}$ NMR spectrum of the reaction mixture of 1 and ${ }^{13} \mathrm{CO}$ (Fig. S10 $\dagger$ ), further confirming its formation in that transformation. Overall, these data conclusively demonstrate that complex $\mathbf{5}$ is formed during reduction of $\left[\mathrm{K}(18-\right.$ crown-6) $]\left[\mathrm{L}^{t \mathrm{Bu}} \mathrm{Ni}^{\mathrm{II}}\left(\eta^{2}-\mathrm{SO}\right)\right](\mathbf{1})$ with $\mathrm{CO}$.

\section{Synthesis of an $\left[\kappa^{2}-\mathrm{CO}_{3}\right]^{2-}$ complex}

To further support the formation of $\left[\mathrm{K}\left(18\right.\right.$-crown-6)][ $\mathrm{L}^{t \mathrm{Bu}} \mathrm{Ni}\left(\kappa^{2}-\right.$ $\left.\mathrm{CO}_{3}\right)$ ] (6) upon reaction of $\mathbf{1}$ with $\mathrm{CO}$, we pursued its synthesis

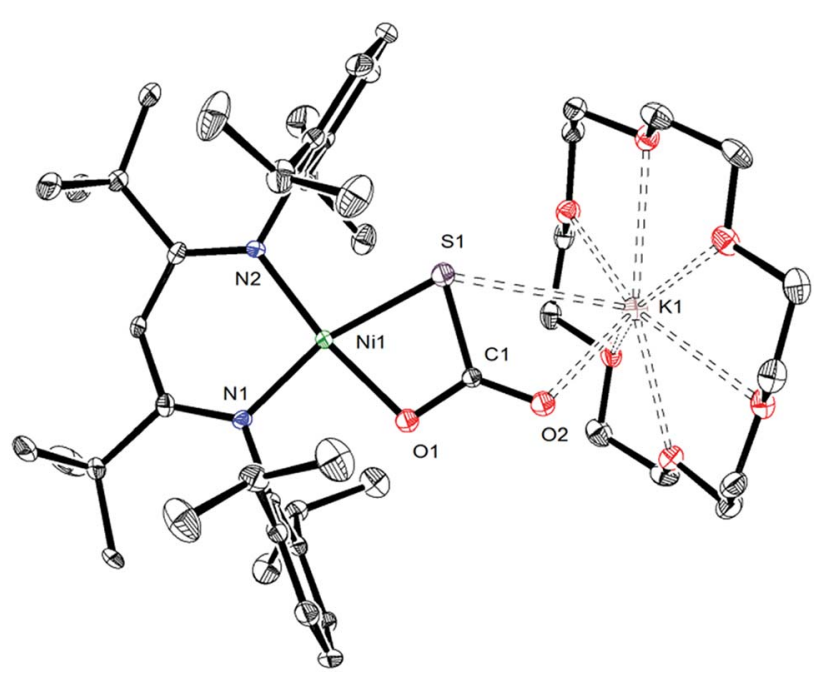

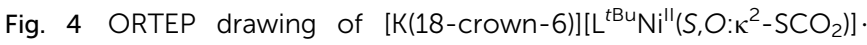
$1.5 \mathrm{C}_{7} \mathrm{H}_{8}\left(5 \cdot 1.5 \mathrm{C}_{7} \mathrm{H}_{8}\right)$ shown with $50 \%$ thermal ellipsoids. Hydrogen atoms, $\mathrm{C}_{7} \mathrm{H}_{8}$ solvate molecules, and one orientation of the disordered $\left[\mathrm{S}, \mathrm{O}: \mathrm{K}^{2}-\mathrm{SCO}_{2}\right]^{2-}$ ligand have been omitted for clarity. Selected

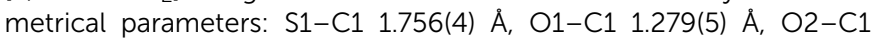
1.238(4) Å, Ni1-S1 2.234(1) A, Ni1-O1 1.922(3) A, Ni1-N1 1.904(3) A,

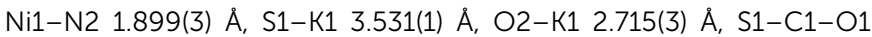

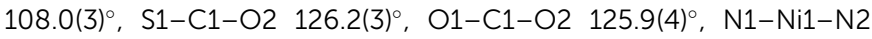
96.7(1) ${ }^{\circ}, \mathrm{N} 1-\mathrm{Ni1}-\mathrm{O} 191.5(1)^{\circ}, \mathrm{N} 2-\mathrm{Ni1}-\mathrm{S} 199.22(9)^{\circ}$. via an independent route. The hexameric nickel carbonate complex, $[\mathrm{K}]_{6}\left[\mathrm{~L}^{t \mathrm{Bu}} \mathrm{Ni}^{\mathrm{II}}\left(\kappa^{2}-\mathrm{CO}_{3}\right)\right]_{6},{ }^{11}$ first reported by Limberg and coworkers in 2012, was found to serve as a convenient starting material for the synthesis of $\left[\mathrm{K}\left(18\right.\right.$-crown-6)][ $\left.\mathrm{L}^{t \mathrm{Bu}} \mathrm{Ni}^{\mathrm{II}}\left(\kappa^{2}-\mathrm{CO}_{3}\right)\right]$ (6). Addition of 6 equiv. of 18-crown- 6 to a suspension of $[\mathrm{K}]_{6}$ $\left[\mathrm{L}^{t \mathrm{Bu}} \mathrm{Ni}^{\mathrm{II}}\left(\kappa^{2}-\mathrm{CO}_{3}\right)\right]_{6}$ results in the formation of complex 6 in $52 \%$ yield (eqn (5)). Its solid state molecular structure is shown in Fig. 5. The carbonate $\left(\mathrm{CO}_{3}{ }^{2-}\right)$ ligand in 6 features a $\mu: \kappa^{2}, \eta^{1}$ binding mode, identical to that observed for the trithiocarbonate $\left(\mathrm{CS}_{3}{ }^{2-}\right)$ ligand in $\left[\mathrm{K}\left(18\right.\right.$-crown-6)][$\left[\mathrm{L}^{t \mathrm{Bu}} \mathrm{Ni}\left(\kappa^{2}-\mathrm{CS}_{3}\right)\right]{ }^{50}$ The

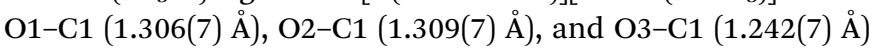
bond lengths in 6 are consistent with those reported for $[\mathrm{K}]_{6^{-}}$ $\left[\mathrm{L}^{t \mathrm{Bu}} \mathrm{Ni}^{\mathrm{II}}\left(\kappa^{2}-\mathrm{CO}_{3}\right)\right]_{6},{ }^{11}$ while the Ni-O1 and $\mathrm{Ni}-\mathrm{O} 2$ distances are 1.882(4) and 1.901(4) $\AA$, respectively, which are similar to those reported for the starting material.

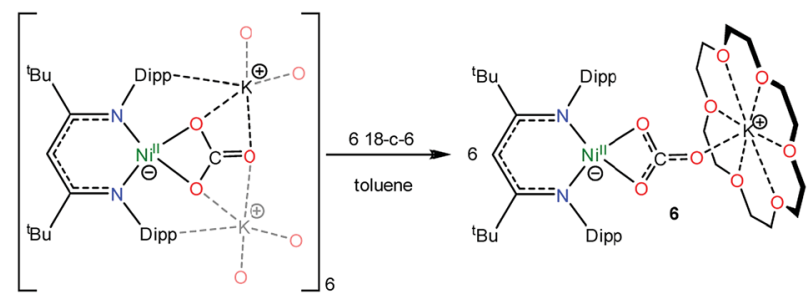

The ${ }^{13} \mathrm{C}\left\{{ }^{1} \mathrm{H}\right\}$ NMR spectrum of 6 in $\mathrm{C}_{6} \mathrm{D}_{6}$ features a resonance at $165.3 \mathrm{ppm}$, which is assignable to the $\left[\mathrm{CO}_{3}\right]^{2-}$ moiety (Fig. S15†). This chemical shift matches the resonance assigned to this complex in the in situ ${ }^{13} \mathrm{C}$ NMR spectrum of the reaction mixture of 1 and ${ }^{13} \mathrm{CO}$ (Fig. S11 $\dagger$ ). In addition, the ${ }^{1} \mathrm{H}$ NMR spectrum of 6 in $\mathrm{C}_{6} \mathrm{D}_{6}$ features a $\gamma-\mathrm{CH}$ resonance at $5.42 \mathrm{ppm}$,

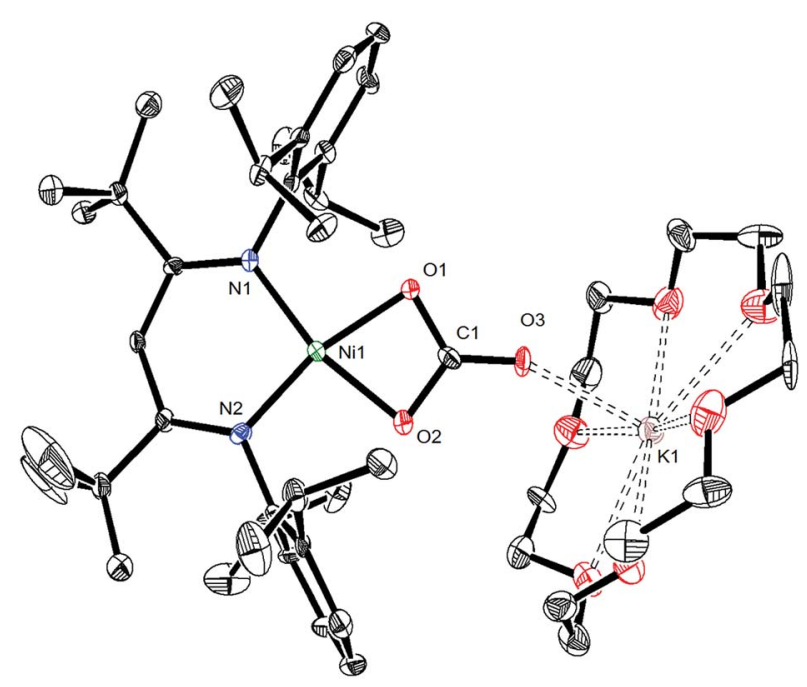

Fig. 5 ORTEP drawing of $[K(18-$ crown- 6$)]\left[L^{t B u} \mathrm{Ni}^{\prime \prime}\left(\kappa^{2}-\mathrm{CO}_{3}\right)\right] \cdot 0.5 \mathrm{C}_{5} \mathrm{H}_{12}$ $\left(6 \cdot 0.5 \mathrm{C}_{5} \mathrm{H}_{12}\right)$ shown with $50 \%$ thermal ellipsoids. Hydrogen atoms, a $\mathrm{C}_{5} \mathrm{H}_{12}$ solvate molecule, and a second independent molecule of

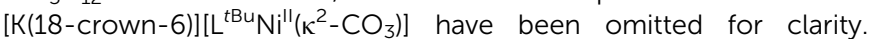
Selected metrical parameters: C1-O1 1.306(7) A, C1-O2 1.309(7) $\AA$, $\mathrm{C} 1-\mathrm{O} 3$ 1.242(7) Å, Ni1-O1 1.882(4) A, Ni1-O2 1.901(4) A, Ni1-N1 1.883(5) Å, Ni1-N2 1.879(5) A, O3-K1 2.510(4) Å, O1-C1-O2 110.8(5) , $\mathrm{O} 1-\mathrm{C} 1-\mathrm{O} 3125.0(6)^{\circ}, \mathrm{N} 1-\mathrm{Ni} 1-\mathrm{N} 29^{97.9}(2)^{\circ}, \mathrm{N} 1-\mathrm{Ni} 1-\mathrm{O} 1$ 96.6(2) $)^{\circ}, \mathrm{N} 2-$ $\mathrm{Ni1}-\mathrm{O} 2$ 96.5(2) ${ }^{\circ}$. 
which is present in the in situ ${ }^{1} \mathrm{H}$ NMR spectrum of the reaction mixture of 1 and ${ }^{13} \mathrm{CO}$ (Fig. S10†). The IR spectrum (hexanes solution) of 6 features a strong $v_{\mathrm{CO}}$ mode at $1620 \mathrm{~cm}^{-1}$, which is also present in a solution IR spectrum of the reaction mixture formed upon addition of CO to $\mathbf{1}$ (Fig. S24†). Overall, these data conclusively demonstrate that complex 6 is formed during reduction of $\left[\mathrm{K}(18-\right.$ crown-6) $)\left[\mathrm{L}^{t \mathrm{Bu}} \mathrm{Ni}^{\mathrm{II}}\left(\eta^{2}-\mathrm{SO}\right)\right](\mathbf{1})$ with $\mathrm{CO}$.

\section{Synthesis of an $\left[\eta^{2}-\mathrm{CO}_{2}\right]^{2-}$ complex}

In an effort to assign the resonance at $191.4 \mathrm{ppm}$ in the in situ ${ }^{13} \mathrm{C}\left\{{ }^{1} \mathrm{H}\right\}$ NMR spectrum of the reaction of 1 and ${ }^{13} \mathrm{CO}$, we endeavored to independently synthesize the carbon dioxide complex, $[\mathrm{K}(18$-crown-6) $)]\left[\mathrm{L}^{t \mathrm{Bu}} \mathrm{Ni}^{\mathrm{II}}\left(\eta^{2}-\mathrm{CO}_{2}\right)\right](10)$. We rationalized that $\mathbf{1 0}$ was a plausible reaction product, given the formation of $\mathrm{CO}_{2}$ during the reaction (see below). Several previously reported $\mathrm{Ni}\left(\mathrm{CO}_{2}\right)$ complexes have been synthesized by reaction of $\mathrm{CO}_{2}$ with a $\mathrm{Ni}^{0}$ precursor ${ }^{61-64}$ In a similar vein, the $\mathrm{Ni}(0)-\mathrm{N}_{2}$ complex, $[\mathrm{K}]_{2}\left[{ }^{\mathrm{tBu}} \mathrm{Ni}^{0}\left(\mu-\eta^{1}: \eta^{1}-\mathrm{N}_{2}\right) \mathrm{Ni}^{0}{ }^{\mathrm{tBu}}\right]$, previously reported by Limberg and co-workers in $2009,{ }^{65}$ was found to serve as an effective $\mathrm{Ni}^{0}$ source for the synthesis of $\mathbf{1 0}$. Thus, exposure of $[\mathrm{K}]_{2}\left[\mathrm{~L}^{t \mathrm{Bu}} \mathrm{Ni}^{0}(\mu-\right.$ $\left.\left.\eta^{1}: \eta^{1}-\mathrm{N}_{2}\right) \mathrm{Ni}^{0} \mathrm{~L}^{t \mathrm{Bu}}\right]$ to two equiv. of $\mathrm{CO}_{2}$, followed by addition of 18-crown-6, resulted in the formation of $\mathbf{1 0}$ (eqn (6)), which was isolated as pale orange plates in $41 \%$ yield after work-up. Its formulation was confirmed by X-ray crystallography and its solid state molecular structure is shown in Fig. 6.
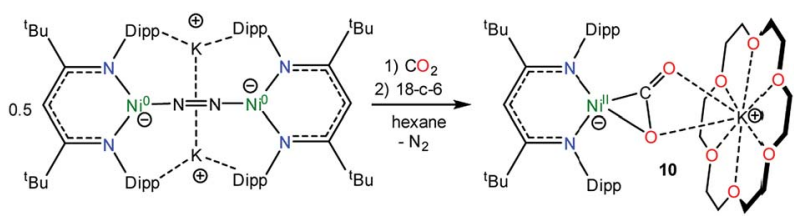

Complex 10 features a square planar $\mathrm{Ni}^{\mathrm{II}}$ center ligated by the $\beta$-diketiminate ligand and a $\left[\mathrm{CO}_{2}\right]^{2-}$ ligand. The $\left[\mathrm{CO}_{2}\right]^{2-}$ ligand in 10 features a $\mu: \eta^{2}, \kappa^{2}$ binding mode, similar to that observed for the $[\mathrm{COS}]^{2-}$ ligand in complex 4. The $\left[\mathrm{CO}_{2}\right]^{2-}$ ligand in $\mathbf{1 0}$ is disordered over two positions, in a $76: 24$ ratio, which are related by a $C_{2}$ rotation axis about the Ni-K vector. The Ni1-O1 $(1.897(6) \AA)$ and Ni1-C1 (1.890(6) ̊̊) distances are consistent with those previously reported for the $\mathrm{Ni}\left(\eta^{2}-\mathrm{CO}_{2}\right)$ fragment. ${ }^{61,62,64,66,67}$ Additionally, the Ni-N bonds in 10 are consistent with those found in other square planar $\mathrm{Ni}^{\mathrm{iI}} \beta$-diketiminate complexes. ${ }^{16,49,50}$

The ${ }^{1} \mathrm{H}$ NMR spectrum of $\mathbf{1 0}$ in $\mathrm{C}_{6} \mathrm{D}_{6}$ is consistent with that expected for a $C_{\mathrm{s}}$ symmetric, square planar $\mathrm{Ni}^{\mathrm{iI}}$ complex. It features two tert-butyl resonances at 1.42 and $1.34 \mathrm{ppm}$, and a single $\gamma$-CH resonance at $5.42 \mathrm{ppm}$. Its ${ }^{13} \mathrm{C}\left\{{ }^{1} \mathrm{H}\right\}$ NMR spectrum in $\mathrm{C}_{6} \mathrm{D}_{6}$ features a resonance at $167.2 \mathrm{ppm}$, which we have assigned to the $\left[\eta^{2}-\mathrm{CO}_{2}\right]^{2-}$ ligand. This chemical shift is consistent with those reported for previously isolated $\mathrm{Ni}\left(\eta^{2}-\right.$ $\mathrm{CO}_{2}$ ) complexes. ${ }^{62-64}$ Most importantly, however, these resonances are not observed in the in situ ${ }^{13} \mathrm{C}\left\{{ }^{1} \mathrm{H}\right\}$ and ${ }^{1} \mathrm{H}$ NMR spectra of the reaction between 1 and ${ }^{13} \mathrm{CO}$ (Fig. S10 and 11†). Thus, we can definitively conclude that complex $\mathbf{1 0}$ is not being formed in that reaction. Finally, complex 10 features a $v_{\mathrm{CO}}$ mode at $1664 \mathrm{~cm}^{-1}$ in its IR spectrum ( $\mathrm{KBr}$ pellet), which is

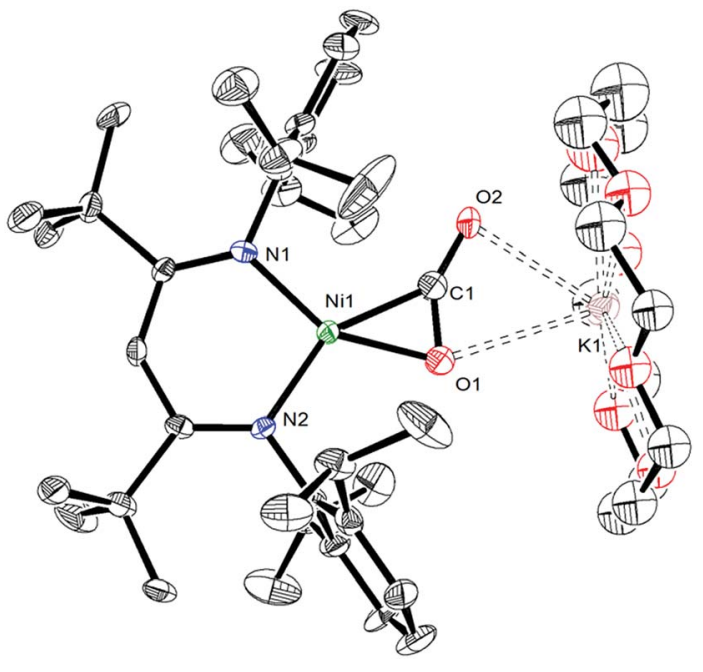

Fig. 6 ORTEP drawing of $\left[K\left(18-\right.\right.$ crown-6)] $\left[L^{t B u} \mathrm{Ni}^{\prime \prime}\left(\eta^{2}-\mathrm{CO}_{2}\right)\right] \cdot 2 \mathrm{C}_{6} \mathrm{H}_{6}$ $\left(10 \cdot 2 \mathrm{C}_{6} \mathrm{H}_{6}\right)$ shown with $50 \%$ thermal ellipsoids. Hydrogen atoms, $\mathrm{C}_{6} \mathrm{H}_{6}$ solvate molecules, and second orientations of the $\mathrm{CO}_{2}$ and 18-crown6 fragments have been omitted for clarity. Selected metrical parameters: C1-O1 1.231(9) A, C1-O2 1.22(1) A, Ni1-C1 1.890(6) A, Ni1-O1 1.897(6) Å, Ni1-N1 1.901(6) A, Ni1-N2 1.896(5) A, O1-K1 2.980(6) Å, $\mathrm{O} 2-\mathrm{K} 12.71(1) \AA ̊ . \mathrm{O} 1-\mathrm{C} 1-\mathrm{O} 2144.0(8)^{\circ}, \mathrm{N} 1-\mathrm{Ni} 1-\mathrm{N} 2$ 99.2(2) ${ }^{\circ}, \mathrm{N} 1-\mathrm{Ni1}-$ C1 $112.2(3)^{\circ}, \mathrm{N} 2-\mathrm{Ni} 1-\mathrm{O} 1110.7(3)^{\circ}$.

similar to those reported for other nickel $\mathrm{CO}_{2}$ complexes. ${ }^{62-64}$ This vibration is also not present in the in situ IR spectrum (recorded in hexanes) of the reaction residue formed upon reaction of 1 with $\mathrm{CO}$ (Fig. S24†).

\section{Mechanistic considerations}

To rationalize the formation of complexes 4 and $\mathbf{5}$, we propose that $\mathrm{CO}$ initially reacts with 1 to form $\mathrm{CO}_{2}$ and [K(18-crown-6)] $\left[\mathrm{L}^{t \mathrm{Bu}} \mathrm{Ni}^{\mathrm{II}}(\mathrm{S})\right](\mathrm{I})$ (Scheme 2). Complex I then reacts with either $\mathrm{CO}$

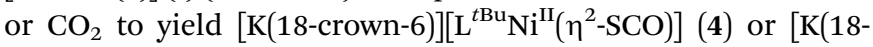

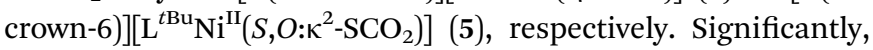
their presence, along with the observation of [K(18-crown-6)] $\left[\mathrm{L}^{t \mathrm{Bu}} \mathrm{Ni}^{\mathrm{II}}(\mathrm{S})\right](\mathrm{I})$ in the reaction mixture, demonstrates the formal reduction of $\mathrm{N}_{2} \mathrm{O}$ by $\mathrm{CO}$, as originally envisioned. That said, the reaction rates of $\mathbf{I}$ with $\mathrm{CO}$ and $\mathrm{CO}_{2}$ are qualitatively similar to the reaction rate of $\mathbf{I}$ with $\mathrm{N}_{2} \mathrm{O}$. As a consequence, $\mathbf{I}$ is unlikely to be an effective catalyst for $\mathrm{N}_{2} \mathrm{O}$ reduction because off-cycle reactions with $\mathrm{CO}$ and $\mathrm{CO}_{2}$ would be competitive with the desired $\mathrm{N}_{2} \mathrm{O}$ capture reaction (Scheme 2).

To rationalize the formation of complex 6 and COS, we propose that reaction of the newly formed $\mathrm{CO}_{2}$ with unreacted 1 results in the formation of a transient, unobserved nickel monothiopercarbonate complex, $[\mathrm{K}(18-$ crown- 6$)]\left[\mathrm{L}^{t \mathrm{Bu}} \mathrm{Ni}^{\mathrm{II}}\left(\kappa^{2}-\right.\right.$ $\left.\mathrm{SOCO}_{2}\right)$ ] (11). Complex 11 then transfers a sulfur atom to $\mathrm{CO}$ to

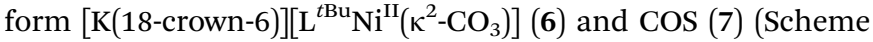
2 ), both of which were confirmed to be present in the in situ reaction mixture. This hypothesis also nicely explains the presence of $\left[\mathrm{K}\left(18-\right.\right.$ crown-6)][ $\left.\mathrm{L}^{t \mathrm{Bu}} \mathrm{Ni}^{\mathrm{iI}}\left(\kappa^{2}-\mathrm{S}_{2} \mathrm{CO}\right)\right](8)$, which could be formed via the reaction of 7 with I (Scheme 2). While a monothiopercarbonate complex has not been previously reported, the reaction of metal peroxides $\left(\mathrm{O}_{2}{ }^{2-}\right)$ with $\mathrm{CO}_{2}$ is 


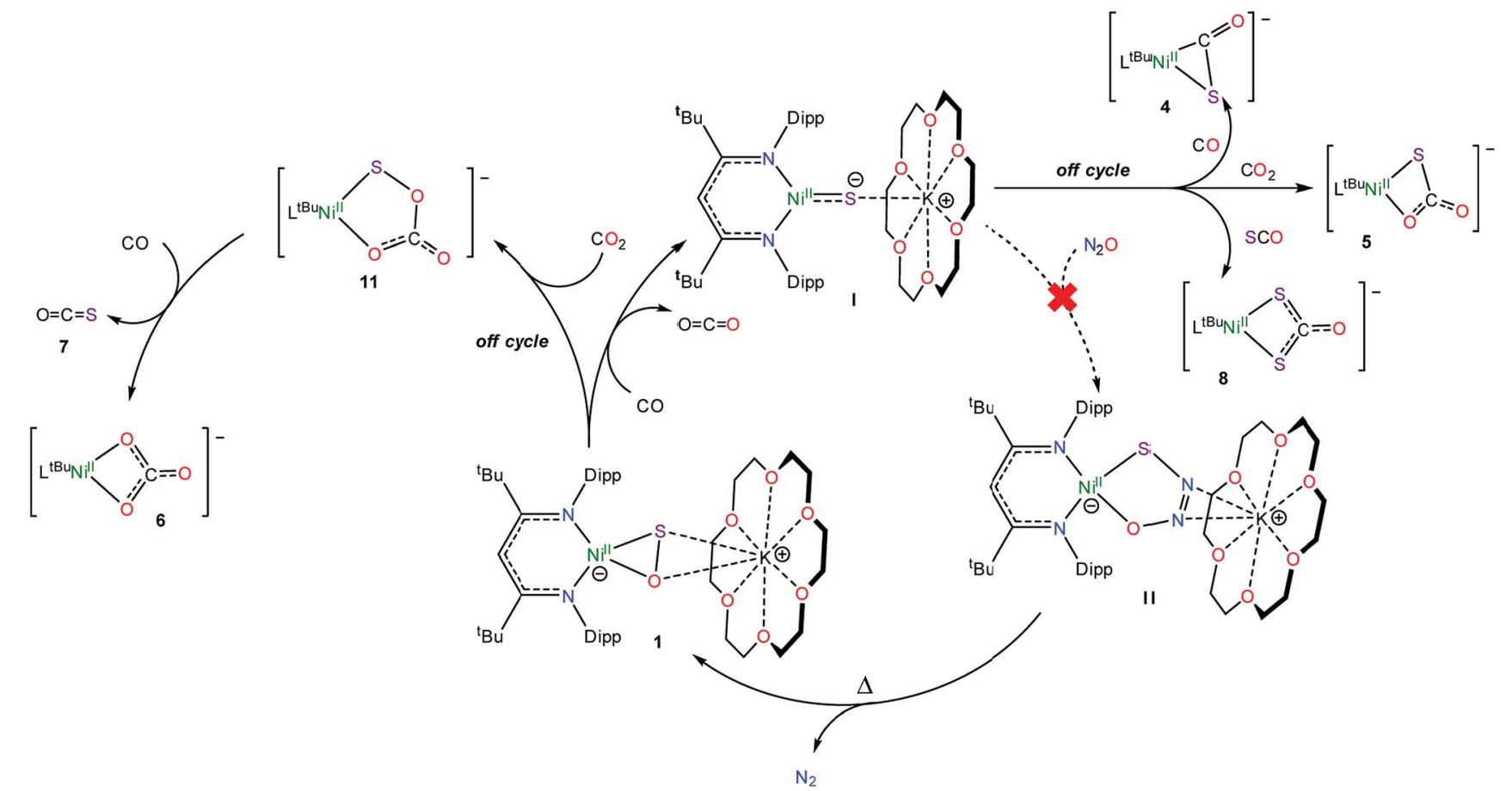

Scheme 2

known to yield peroxocarbonate $\left(\left[\mathrm{OOCO}_{2}\right]^{2-}\right)$ complexes. $^{68-71}$ Similarly, metal disulfides $\left(\mathrm{S}_{2}{ }^{2-}\right)$ are known to react with $\mathrm{CS}_{2}$ to form perthiocarbonates $\left(\left[\mathrm{SSCS}_{2}\right]^{2-}\right){ }^{72,73}$ Moreover, peroxocarbonates are known to be very effective O-atom donors. ${ }^{69,74-77}$

Consistent with this hypothesis, reaction of [K(18-crown-6)] $\left[\mathrm{L}^{t \mathrm{Bu}} \mathrm{Ni}^{\mathrm{II}}\left(\eta^{2}-\mathrm{SO}\right)\right](\mathbf{1})$ with $\mathrm{CO}_{2}$ in $\mathrm{C}_{6} \mathrm{D}_{6}$ results in the rapid formation of a new diamagnetic $\mathrm{Ni}^{\mathrm{II}}$ complex, as evidenced by the appearance of diagnostic resonances at $4.49 \mathrm{ppm}(\gamma-\mathrm{CH})$ and $1.20 \mathrm{ppm}(t \mathrm{Bu})$ in the in situ ${ }^{1} \mathrm{H}$ NMR spectrum of the reaction mixture (Fig. $\mathrm{S} 18 \dagger$ ). We have assigned these resonances to the monothiopercarbonate complex [K(18-crown-6)] $\left[\mathrm{L}^{t \mathrm{Bu}} \mathrm{Ni}^{\mathrm{II}}\left(\kappa^{2}-\mathrm{SOCO}_{2}\right)\right]$ (11) (eqn (7)). Complex $\mathbf{1 1}$ is the only product observed in the reaction mixture. These results provide further support for the overall reaction mechanism proposed in Scheme 2 and suggest that $\left(\mathrm{SOCO}_{2}\right)^{2-}$ could function as a very effective a S-atom transfer reagent. ${ }^{78}$

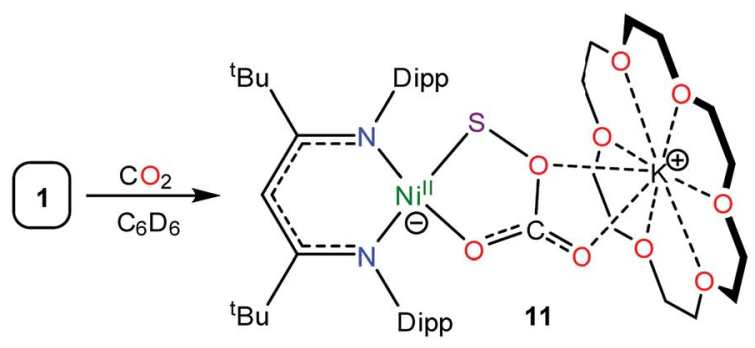

\section{Conclusions}

Gentle thermolysis of the thiohyponitrite complex, [K(18-crown6) $]\left[\mathrm{L}^{t \mathrm{Bu}} \mathrm{Ni}^{\mathrm{II}}\left(\kappa^{2}-\mathrm{SNNO}\right)\right]$, results in extrusion of $\mathrm{N}_{2}$ and formation of $\left[\mathrm{K}\left(18\right.\right.$-crown-6)][L $\left.\mathrm{L}^{t \mathrm{Bu}} \mathrm{Ni}^{\mathrm{II}}\left(\eta^{2}-\mathrm{SO}\right)\right]$, a rare example of a structurally characterized SO complex, along with trace

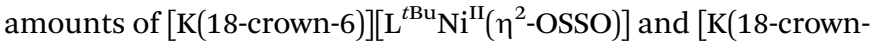
$6)]\left[\mathrm{L}^{t \mathrm{Bu}} \mathrm{Ni}^{\mathrm{II}}\left(\eta^{2}-\mathrm{S}_{2}\right)\right] . \quad\left[\mathrm{K}(18-\right.$ crown-6) $]\left[\mathrm{L}^{t \mathrm{Bu}} \mathrm{Ni}^{\mathrm{II}}\left(\eta^{2}-\mathrm{SO}\right)\right]$ reacts rapidly with $\mathrm{CO}$, forming the "masked" terminal $\mathrm{Ni}(\mathrm{II})$ sulfide intermediate, $\left[\mathrm{K}\left(18\right.\right.$-crown-6)][ $\left.\mathrm{L}^{t \mathrm{Bu}} \mathrm{Ni}^{\mathrm{II}}(\mathrm{S})\right]$, along with $\mathrm{CO}_{2}$, via $\mathrm{O}$ atom abstraction. This $\mathrm{Ni}$ (II) sulfide intermediate then reacts

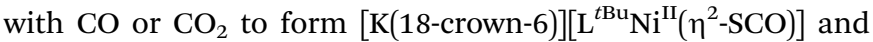
$\left[\mathrm{K}\left(18\right.\right.$-crown-6)][ $\left.\mathrm{L}^{t \mathrm{Bu}} \mathrm{Ni}\left(S, O: \kappa^{2}-\mathrm{SCO}_{2}\right)\right]$, respectively. [K(18-crown6) $]\left[\mathrm{L}^{t \mathrm{Bu}} \mathrm{Ni}^{\mathrm{II}}\left(\eta^{2}-\mathrm{SO}\right)\right]$ can also react with the newly formed $\mathrm{CO}_{2}$ to form a putative monothiopercarbonate complex, [K(18-crown6) $]\left[\mathrm{L}^{t \mathrm{Bu}} \mathrm{Ni}^{\mathrm{II}}\left(\kappa^{2}-\mathrm{SOCO}_{2}\right)\right]$, which can then transfer an $\mathrm{S}$ atom to $\mathrm{CO}$, forming COS and $\left[\mathrm{K}(18-\right.$ crown-6) $]\left[\mathrm{L}^{t \mathrm{Bu}} \mathrm{Ni}^{\mathrm{II}}\left(\kappa^{2}-\mathrm{CO}_{3}\right)\right]$.

Significantly, the observation of $\left[\mathrm{K}\left(18\right.\right.$-crown-6)][ $\left.\mathrm{L}^{t \mathrm{Bu}} \mathrm{Ni}^{\mathrm{II}}(\mathrm{S})\right]$ in the reaction mixture, along with the formation of $[\mathrm{K}(18$ -

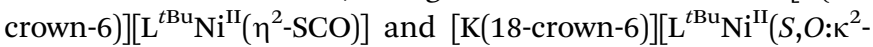
$\left.\mathrm{SCO}_{2}\right)$ ], confirms that the SO ligand is susceptible to O-atom abstraction by $\mathrm{CO}$, which had not been previously demonstrated. More importantly, these reaction products reveal the stepwise conversion of $\left[\mathrm{K}\left(18-\right.\right.$ crown-6)][ $\left.\mathrm{L}^{t \mathrm{Bu}} \mathrm{Ni}^{\mathrm{II}}\left(\kappa^{2}-\mathrm{SNNO}\right)\right]$ to

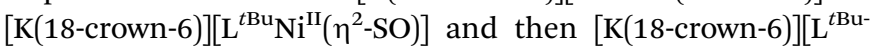
$\left.\mathrm{Ni}^{\mathrm{II}}(\mathrm{S})\right]$, which represents a formal reduction of $\mathrm{N}_{2} \mathrm{O}$ by $\mathrm{CO}$, forming $\mathrm{N}_{2}$ and $\mathrm{CO}_{2}$. Significantly, this transformation parallels the chemistry mediated by nano-particulate $\mathrm{Pt} / \mathrm{Rh}$ in catalytic converters. In contrast to the metal-centered redox of the catalytic converter example, however, the redox chemistry in our system occurs at the sulfide ligand, while the nickel center remains in the $2+$ oxidation state at every step. The use of ligand-centered redox is an intriguing strategy for $\mathrm{N}_{2} \mathrm{O}$ reduction and we suggest that the study of model systems, such as the one presented in this manuscript, could inspire the design of a new generation of homogeneous and heterogeneous $\mathrm{N}_{2} \mathrm{O}$ reduction catalysts. 


\section{Conflicts of interest}

The authors declare no competing financial interests.

\section{Acknowledgements}

We thank the National Science Foundation (CHE 1361654) for financial support of this work. We would also like to thank the Scott Group at UCSB for the use of their ${ }^{13} \mathrm{CO}$. This research made use of the $400 \mathrm{MHz}$ NMR Spectrometer in the Department of Chemistry and Biochemistry, an NIH SIG (1S10OD01207701A1).

\section{References}

1 A. R. Ravishankara, J. S. Daniel and R. W. Portmann, Science, 2009, 326, 123-125.

2 W. C. Trogler, Coord. Chem. Rev., 1999, 187, 303-327.

3 A. V. Leontev, O. g. A. Fomicheva, M. V. Proskurnina and N. S. Zefirov, Russ. Chem. Rev., 2001, 70, 91.

4 M. J. Prather, Science, 1998, 279, 1339-1341.

5 E. A. Davidson and D. Kanter, Environ. Res. Lett., 2014, 9, 105012.

6 M. Konsolakis, ACS Catal., 2015, 5, 6397-6421.

7 B. Neuffer, N. Frank and M. Desai, Available and Emerging Technologies for Reducing Greenhouse Gas Emissions from the Nitric Acid Production Industry, Report of the Office of Air and Radiation, U.S. Environmental Protection Agency, Research Triangle Park, NC, 2010.

8 M. Dameris, Angew. Chem., Int. Ed., 2010, 49, 489-491.

9 P. Granger and V. I. Parvulescu, Chem. Rev., 2011, 111, 31553207.

10 J. P. Reeds, B. L. Yonke, P. Y. Zavalij and L. R. Sita, J. Am. Chem. Soc., 2011, 133, 18602-18605.

11 B. Horn, C. Limberg, C. Herwig, M. Feist and S. Mebs, Chem. Commun., 2012, 48, 8243-8245.

12 A. W. Kaplan and R. G. Bergman, Organometallics, 1998, 17, 5072-5085.

13 J.-H. Lee, M. Pink, J. Tomaszewski, H. Fan and K. G. Caulton, J. Am. Chem. Soc., 2007, 129, 8706-8707.

14 L. E. Doyle, W. E. Piers and J. Borau-Garcia, J. Am. Chem. Soc., 2015, 137, 2187-2190.

15 R. Zeng, M. Feller, Y. Ben-David and D. Milstein, J. Am. Chem. Soc., 2017, 139, 5720-5723.

16 N. J. Hartmann, G. Wu and T. W. Hayton, Angew. Chem., Int. Ed., 2015, 54, 14956-14959.

17 K. Severin, Chem. Soc. Rev., 2015, 44, 6375-6386.

18 P. Pyykkö, J. Phys. Chem. A, 2015, 119, 2326-2337.

19 F. X. Powell and D. R. Lide Jr, J. Chem. Phys., 1964, 41, 14131419.

20 B. Horn, C. Limberg, C. Herwig and B. Braun, Inorg. Chem., 2014, 53, 6867-6874.

21 C. Bianchini, C. Mealli, A. Meli and M. Sabat, J. Chem. Soc., Chem. Commun., 1985, 1024-1025.

22 A. Neher, O. Heyke and I. P. Lorenz, Z. Anorg. Allg. Chem., 1989, 578, 185-190.
23 R. Huang, I. A. Guzei and J. H. Espenson, Organometallics, 1999, 18, 5420-5422.

24 C. Minh Tuong, W. K. Hammons, A. L. Howarth, K. E. Lutz, A. D. Maduvu, L. B. Haysley, B. R. T. Allred, L. K. Hoyt, M. S. Mashuta and M. E. Noble, Inorg. Chem., 2009, 48, 5027-5038.

25 K. Oya, H. Seino, M. Akiizumi and Y. Mizobe, Organometallics, 2011, 30, 2939-2946.

26 R. Wang, M. S. Mashuta, J. F. Richardson and M. E. Noble, Inorg. Chem., 1996, 35, 3022-3030.

27 L. E. Longobardi, V. Wolter and D. W. Stephan, Angew. Chem., Int. Ed., 2015, 54, 809-812.

28 L. Markó, B. Markó-Monostory, T. Madach and H. Vahrenkamp, Angew. Chem., Int. Ed., 1980, 19, 226-227.

29 J. E. Hoots, D. A. Lesch and T. B. Rauchfuss, Inorg. Chem., 1984, 23, 3130-3136.

30 S. Bagherzadeh and N. P. Mankad, Chem. Commun., 2018, 54, 1097-1100.

31 F. J. Lovas, E. Tiemann and D. R. Johnson, J. Chem. Phys., 1974, 60, 5005-5010.

32 R. D. Harcourt, J. Mol. Struct.: THEOCHEM, 1989, 186, 131165.

33 R. D. Harcourt, Eur. J. Inorg. Chem., 2000, 2000, 1901-1916. 34 M. A. Martin-Drumel, J. van Wijngaarden, O. Zingsheim, F. Lewen, M. E. Harding, S. Schlemmer and S. Thorwirth, J. Mol. Spectrosc., 2015, 307, 33-39.

35 C. J. Marsden and B. J. Smith, Chem. Phys., 1990, 141, 335353.

36 G. Schmid, G. Ritter and T. Debaerdemaeker, Chem. Ber., 1975, 108, 3008-3013.

37 I.-P. Lorenz and J. Kull, Angew. Chem., Int. Ed., 1986, 25, 261262.

38 The other structurally characterized example, $\left[(\text { diphos })_{2} \mathrm{Ir}(\mathrm{OSSO})\right] \mathrm{Cl}$ (diphos $=\mathrm{Ph}_{2} \mathrm{PCH}_{2} \mathrm{CH}_{2} \mathrm{PPh}_{2}$ ), features a trans-OSSO ligand (dihedral angle $=68^{\circ}$ ) with an S-S bond length of $2.041 \AA$ A. Curiously, one of its S-O bond lengths (1.21(2) $\AA$ ) is anomalously short, which may indicate the presence of unresolved disorder in the structure. See ref. 36 .

39 D. E. Smiles, G. Wu and T. W. Hayton, Inorg. Chem., 2014, 53, 12683-12685.

40 Z. K. Sweeney, J. L. Polse, R. A. Andersen, R. G. Bergman and M. G. Kubinec, J. Am. Chem. Soc., 1997, 119, 4543-4544.

41 Z. K. Sweeney, J. L. Polse, R. G. Bergman and R. A. Andersen, Organometallics, 1999, 18, 5502-5510.

42 C. Mealli and S. Midollini, Inorg. Chem., 1983, 22, 2785-2786. 43 R. J. Pleus, H. Waden, W. Saak, D. Haase and S. Pohl, J. Chem. Soc., Dalton Trans., 1999, 2601-2610.

44 J. Cho, K. M. Van Heuvelen, G. P. A. Yap, T. C. Brunold and C. G. Riordan, Inorg. Chem., 2008, 47, 3931-3933.

45 S. Yao, C. Milsmann, E. Bill, K. Wieghardt and M. Driess, J. Am. Chem. Soc., 2008, 130, 13536-13537.

46 M. Inosako, A. Kunishita, M. Kubo, T. Ogura, H. Sugimoto and S. Itoh, Dalton Trans., 2009, 9410-9417.

47 V. M. Iluc, C. A. Laskowski, C. K. Brozek, N. D. Harrold and G. L. Hillhouse, Inorg. Chem., 2010, 49, 6817-6819. 
48 F. Olechnowicz, G. L. Hillhouse and R. F. Jordan, Inorg. Chem., 2015, 54, 2705-2712.

49 S. Yao, Y. Xiong, X. Zhang, M. Schlangen, H. Schwarz, C. Milsmann and M. Driess, Angew. Chem., Int. Ed., 2009, 48, 4551-4554.

50 N. J. Hartmann, G. Wu and T. W. Hayton, Dalton Trans., 2016, 45, 14508-14510.

51 N. J. Hartmann, G. Wu and T. W. Hayton, J. Am. Chem. Soc., 2016, 138, 12352-12355.

52 W. S. Farrell, P. Y. Zavalij and L. R. Sita, Angew. Chem., Int. Ed., 2015, 54, 4269-4273.

53 J. D. E. T. Wilton-Ely, D. Solanki and G. Hogarth, Inorg. Chem., 2006, 45, 5210-5214.

54 R. Lalrempuia, A. Stasch and C. Jones, Chem. Sci., 2013, 4, 4383-4388.

55 B. Horn, S. Pfirrmann, C. Limberg, C. Herwig, B. Braun, S. Mebs and R. Metzinger, Z. Anorg. Allg. Chem., 2011, 637, 1169-1174.

56 R. H. Holm and J. P. Donahue, Polyhedron, 1993, 12, 571589.

57 O. P. Lam, S. M. Franke, F. W. Heinemann and K. Meyer, J. Am. Chem. Soc., 2012, 134, 16877-16881.

58 C. Schoo, S. V. Klementyeva, M. T. Gamer, S. N. Konchenko and P. W. Roesky, Chem. Commun., 2016, 52, 6654-6657.

59 D. E. Smiles, G. Wu and T. W. Hayton, J. Am. Chem. Soc., 2014, 136, 96-99.

60 D. E. Smiles, G. Wu, N. Kaltsoyannis and T. W. Hayton, Chem. Sci., 2015, 6, 3891-3899.

61 A. Döhring, P. W. Jolly, C. Krüger and M. J. Romão, Z. Naturforsch. B Chem. Sci., 1985, 40, 484-488.

62 R. Beck, M. Shoshani, J. Krasinkiewicz, J. A. Hatnean and S. A. Johnson, Dalton Trans., 2013, 42, 1461-1475.
63 Y.-E. Kim, J. Kim and Y. Lee, Chem. Commun., 2014, 50, 11458-11461.

64 J. S. Anderson, V. M. Iluc and G. L. Hillhouse, Inorg. Chem., 2010, 49, 10203-10207.

65 S. Pfirrmann, C. Limberg, C. Herwig, R. Stößer and B. Ziemer, Angew. Chem., Int. Ed., 2009, 48, 3357-3361.

66 C. H. Lee, D. S. Laitar, P. Mueller and J. P. Sadighi, J. Am. Chem. Soc., 2007, 129, 13802-13803.

67 D. Sahoo, C. Yoo and Y. Lee, J. Am. Chem. Soc., 2018, 140, 2179-2185.

68 P. Zimmermann, S. Hoof, B. Braun-Cula, C. Herwig and C. Limberg, Angew. Chem., Int. Ed., 2018, 57, 7230-7233.

69 K. Hashimoto, S. Nagatomo, S. Fujinami, H. Furutachi, S. Ogo, M. Suzuki, A. Uehara, Y. Maeda, Y. Watanabe and T. Kitagawa, Angew. Chem., Int. Ed., 2002, 41, 1202-1205.

70 G. Meier and T. Braun, Angew. Chem., Int. Ed., 2012, 51, 12564-12569.

71 M. Yamashita, K. Goto and T. Kawashima, J. Am. Chem. Soc., 2005, 127, 7294-7295.

72 D. Coucouvanis and M. Draganjac, J. Am. Chem. Soc., 1982, 104, 6820-6822.

73 S.-B. Yu and R. H. Holm, Polyhedron, 1993, 12, 263-266.

74 A. McKillop and W. R. Sanderson, Tetrahedron, 1995, 51, 6145-6166.

75 T. Tsugawa, H. Furutachi, M. Marunaka, T. Endo, K. Hashimoto, S. Fujinami, S. Akine, Y. Sakata, S. Nagatomo, T. Tosha, T. Nomura, T. Kitagawa, T. Ogura and M. Suzuki, Chem. Lett., 2015, 44, 330-332.

76 B. S. Lane, M. Vogt, V. J. DeRose and K. Burgess, J. Am. Chem. Soc., 2002, 124, 11946-11954.

77 H. Yao and D. E. Richardson, J. Am. Chem. Soc., 2000, 122, 3220-3221.

78 J. P. Donahue, Chem. Rev., 2006, 106, 4747-4783. 